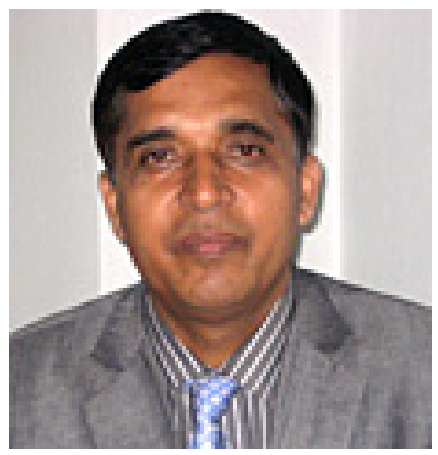

\title{
An Interview with Mr. Balananda Paudel
}

\section{Secretary, Ministry of Energy, Government of Nepal}

\section{Mr. Balananda Paudel granted an Interview on con- current energy scenario of Nepal to Jeewan P. Thanju, Editor-in-Chief of the HYDRO Nepal Journal. Excerpts from the Interview:}

You are the first to Chair the Board of Director of Nepal Electricity Authority (NEA) as the Secretary of Ministry of Energy (MOE), Government of Nepal (GON). How do you perceive the challenges and opportunities faced by the NEA?

Historically NEA's board has been driven by political leadership since its establishment in the year 1985 AD. Transferring its leadership to bureaucracy by the Government of Nepal is indeed a very positive step. While it's an honor for me to become first chair of the board as a Secretary of Ministry of Energy, this portfolio comes with a full of numerous challenges. Power cuts situation prevailing in the country for the past several years and the situation to stay for next few years; extension and development of transmission lines; improvement of financial health of NEA and overall reform of NEA are some of the outstanding challenges. And these issues come with opportunities as well. On one hand there is a need to overhaul NEA as such while on the other, as the challenges, that I stated above, encompass cross sectorial elements-there are opportunities for all of us including Government of Nepal to address the challenges faced by NEA considering the fact that crisis presently faced by NEA is actually a national crisis.

There is a projection of more than 19 hours of black out by NEA in coming months. How the MOE planning to tackle it?

There are several possibilities on which we are working on to bring load shedding to consumers' tolerance level. Firstly, we are in the process of upgrading and utilizing prevailing transmission line infrastructures situated at both sides of Nepal and India to import electricity from India. The last meeting of Nepal India Power exchange committee has agreed to import electricity equivalent to $100 \mathrm{MW}$ within 6 months. That could reduce the load shedding hours by 4-5 hours.

Second option is to install diesel plants. Depending upon the size of the plant and its operation time the load shedding can be substantially reduced. But it comes with a price which is obviously more expensive compared to electricity generated from hydro. I am of opinion that flexibility in running a power system is enhanced if there is a mix in our Integrated Nepal Power System and keeping some "Megawatts" as a backup in the system will certainly increase the reliability of system. In this aspect we are in process to utilize our existing diesel and multi fuel plant. As I said running these plant are expensive and given the financial situation of NEA - we are in the process of requesting Ministry of Finance to cover extra cost attributed while operating diesel and multi fuel plants as a grant to NEA.

Thirdly, we are also looking at option of utilizing captive plants installed by industries and hotels for their own energy consumption. A proposal has been floated and we are looking forward to see the response.

Why MOE/NEA is determined to install large scale Diesel Plant, when NEA cannot repair its existing Multi fuel and Diesel plants even with World Bank (WB) support?

There is no doubt that lead source of energy for our country has to be from hydropower projects. Over the years we have not been able to develop many projects to meet our much needed demand due to various reasons. The installation of diesel plants or using the existing ones is one of the options that will address current electricity deficit scenario. But I will stress again that it is not the cost friendly proposition. If the extra cost can be borne by the country in order to reduce load shedding hours then keeping our INPS as mixed system with small portion of other energy source will not hamper but instead will give NEA more flexibility and reliability in delivering electricity to consumers. But again question will remain - can we bear the cost?

The MOE gives more priority in importing electricity from India and installation of diesel plants rather than facilitating for sustainable hydropower development in the country. Why so?

Presently, we are in electricity crisis situation. We have that situation in the past and it will continue in future if we do not act. Sustainable hydropower development is the fundamental principle of Ministry of Energy. I have already covered about the diesel plant-why it is important and also stated about the cost implications. Importing electricity is on priority and we have made some progress in this regard as I stated while answering previous questions. This does not mean that developing hydropower projects have lesser priority. The other options that we are currently working on are for addressing the current load shedding scenario which may extend several years in future. 
Topics like electricity loss reduction, action on NEA land grabbers etc are not heard in the media. Why MOE and NEA are not active in this regard?

I do not have any comment on first part of your question. I assume that choice of covering the issues basically falls on respective media's prerogative. In case of non technical loss which accounts a substantial percentage of total electricity loss, we have adopted stringent policies. For instance the officer is made accountable and answerable if the feeder under his responsibility is recorded with losses more than $60 \%$. Likewise feeders recording a loss of 40-50\%, 50-60\%, $60-70 \%$ and more than $70 \%$ will have $2 \mathrm{hrs}, 3 \mathrm{hrs}, 4$ hrs and 5 hrs additional power cut respectively. This policy has already shown positive results. Regarding safeguarding land and property of NEA, we have already started building compound walls and taken necessary measures. We are also in the process of moving the court in the cases where we have dispute on land ownership.

The IPPs and the NEA as well are facing numerous limitation and impediments in hydro power development in the country. Many people and the Developers feel that MOE is not vigorous enough in this aspect. What is your view point?

Given the current situation on limitation of lending from financial institutions, field level conditions and lack of effective one window system I acknowledge the developers feeling. However, Ministry has been doing what it can to facilitate IPPs and addressing their concern. In that respect, one of the major incentives given to IPPs is $20 \%$ increment in PPA rate. With this increment dry season and wet season rate has been posted as Rs 8.4 and Rs 4.8 per unit respectively.

Improvement of existing transmission lines and construction of new one is dismal in progress. What are the concrete plan and program of $M O E$ in this regard?

In the past due to financial constraint development of transmission lines has not been progressed in tandem with the development of hydropower plants. This has created a kind of mismatch. Now we are actively working on in improvement of existing and building new transmission line. In coordination with Ministry of Finance we have been working on to secure funding from bilateral and multilateral sources for construction of numerous transmission line projects. 200 million USD has been secured from Indian Line of Credit while 10omillion USD will be made available each from ADB/ Norway and World Bank amounting total of 400 million USD. This will help not only the power evacuation from hydropower projects taken up by NEA but will also ensure transmission of electricity from various hydropower projects initiated by IPPs.
The World Bank supported Power Development Fund (PDF) has very limited participation. Is there any possibilities to transfer this fund to the recently established Hydropower Investment and Development Company (HIDC)?

While establishing this company it has been envisioned that fund from other sources will also be mobilized. But to start with Government of Nepal has allocated fund. After successful mobilization of this fund for hydropower development, there will be a proven case that this company is capable enough to mobilize and administer the fund. In that case possibility to transfer fund from any source is always open. In the meanwhile it has been decided that investment in Kabeli-A hydropower project funded through Power Development Fund will be intermediated through this company.

\section{Why HIDC is so slow in starting its lending activities?}

The office of this company has been established and HIDC is currently in the process of recruiting CEO. To start the lending process HIDC is working to develop various policies like recovery guidelines, operating manuals etc which need be approved from Nepal Ratra Bank. Once these activities are accomplished the lending activities will take pace.

There has been shockingly delay in the maintenance and repair works, funded by the WB, of the Duhabi Multi Fuel Plant, and Diesel Plant (Hetaunda). What could be the reason?

Yes, there has been delay and we are trying to work it out. For Multifuel plant, Watsila Company of Finland has been approached and negotiation has to be made. As the company has not shown much interest to get involved because of limited scope of work, we are in touch with Embassy of Finland for expediting the process as early as possible. In case of diesel plant repair work is being carried out.

What is the present status of proposed Draft Electricity Act and the Draft Regulatory Act submitted in the parliament? When do you expect it to be approved?

Several round of meetings, deliberations and discussion have been held in parliamentary committee. A subcommittee has also been formed to review the draft and it will give its report to parliamentary committee. We hope to get approval as early as possible however it depends upon approval process of parliament.

The hydro projects awarded to the developers through tendering by Department of Electricity Development have become non starter due to dispute in PPA rates and the lack of transmission lines promised by the government. What actions $M O E$ is considering? 
The issue on PPA rates has been settled and the execution of it will require some administrative formalization. As far as transmission line is concerned government is committed to provide transmission access; and we have already secured fund for Solu corridor and Kosi corridor transmission line projects from Indian Line of Credit and thus I don't see any problem in transmission line.

Most of the Industrial areas are in the eastern region; whereas most of the existing and proposed hydropower projects are in the west. Why there are such mismatch and no priority for hydro project in the east?

There are existing and under construction hydropower projects in the east as well-though I agree they are of smaller capacities. But there are several hydropower projects proposed in that region with large capacities. So it cannot be concluded that there is no priority for the eastern region.

Two Finance Ministers have declared in Parliament during the Budget Speech that there will be no license requirement for hydropower projects upto 3MW. It is also proposed in the Draft Electricity Act submitted. Why there is no hurry to implement this provision?

The licensing is primarily dealt according to prevailing Electricity Act 2049 and its regulation 2050. The provision stipulated on draft act can only be implemented once it is enacted. As this draft act is under the parliamentary business it is now the responsibility of parliament.

The National Parks and Wildlife Conservation Department (NPWCD) has very stringent rules that discourage the hydropower projects even in the Buffer zones; whereas the Department has policy to make the local populace benefitted by the exploitation of the local resources. Why there is not uniform and coordinated approach for hydropower friendly environment in the country?

The first part of your statement relates to the said department and I don't have any comments on that. As far as uniform and coordinated approach is concerned every ministry has their own policies, acts and regulations approved by cabinet and parliament. And those ministries are bound to act accordingly. Once you have policies, laws and regulation that bind yourself in implementing sector wide biased policies then your aim would be to achieve sector specific goals. Development of hydropower is such a sector it cross cuts many other sectors and so do other infrastructure development sectors. Thus to have a uniform and coordinated approach there is need of strong, effective and efficient "One Window" which has the authority to settle issues not only related to forest but also every issues and problems that relate to other different sectorial ministries.

Theneighboring countries has benefited from the carbon trading of hydropower projects through CDM. The carbon trading could be an additional funding tool for hydropower development. What the MOE is doing in this regards?

$\mathrm{CDM}$ and carbon related trading comes under the purview of Ministry of Environment as it is the Designated National Authority (DNA). We have been providing necessary advice and feedback to DNA as and when required.

Would you like to convey some messages to the stakeholders related with energy sector through this journal?

We all know Nepal is facing acute electricity shortage and will be severe if we continue to act in as usual business manner. The gravity of situation is such that it has to be recognized and acted upon as national issue rather than sectorial issue. We as a sector ministry will do whatever we can to tackle this situation but as this is a national problem all help and support from every stakeholders is required in order to see off the load shedding forever.

Thank you, Mr. Poudel. HYDRO Nepal Team wishes you all the success as the secretary of $M O E$ and Chairperson of the NEA.

Thank you very much for giving me an opportunity to share my thoughts to readers through your magazine.

\section{CALENDAR OF EVENTS - RAINWATER HARVESTING}

20-24 May, 2012: 3rd IWA Rainwater Harvesting Management International conference. Location: Goseong, Korea. Contact Email: mohsen_tj63@yahoo.com. More info: www.3rwhm.org.

\section{Short Courses}

Large numbers of short courses are offered by UNESCO-IHE, Netherland (Delft) which can be assessed in www.unesco-ihe.org/Education/Non-degree-Programmes/Short-courses/(sort_by)/title

Some of the courses are mentioned below:

2-2o July, 2012: Watershed and River Basin Management

2-20 April, 2012: Water Resources Planning

10-23 September, 2012: Small Hydropower Development - From Planning to Design

23 April to 11 May, 2012: Introduction to River Flood Modeling

11- 29 June, 2012: Flood Risk Management

12 February to 2 March, 2012: Conventional Surface Water Treatment

5-23 March, 2012: Constructed Wetlands for Waste Water Treatment. 